\title{
2: $27351909-273738305$
}

National Cancer Institute

\section{Source}

National Cancer Institute. 2:27351909-273738305. NCI Thesaurus. Code C41818.

Physical location of CAD_Gene 